\title{
Școala Română din Paris (Fontenay-aux-Roses) - file semnificative din istoria unei instituții românești dispărute în negura timpului \\ Vasile-George URSU
}

\begin{abstract}
The beginning of the twentieth century was strongly marked by the First World War. Among the unexpected results of this conflagration we can observe an exponential growth of cultural relations between the states involved in the conflict on the same side. If we explicitly look at the Romanian-French cultural relations from this perspective, it becomes obvious that we are dealing with an exceptional example of cultural collaboration on the European continent. The first concrete step of this process was the signing in Bucharest, on June 15, 1919, of The Poincaré-Angelescu Educational Convention, a document according to which the French state provided its support for the consolidation of Romanian education, especially in the new provinces that entered the Romanian state. Thus, in Bucharest, the French university mission was created as a separate entity, as a result of this convention. Later, in 1924, it was reorganized into the French Institute of Higher Studies. Through these two concrete actions, the French state took the initiative and offered its promised support for its "Latin sister in Eastern Europe". In the same period, the actions of the Kingdom of Romania in this sense were much slower and more indecisive, requiring a private initiative of the historian N. Iorga. This initiative led to discussions held in Bucharest concerning the establishment of two Romanian Schools in France and Italy. In the case of the Romanian School in France, historian N. Iorga took care of all the organizational efforts aimed at establishing this institution, e.g.: choosing a building in the picturesque suburb of Paris - Fontenay-aux-Roses, which he bought on behalf of the Romanian state, proposing a special law for creating these schools in the Romanian Parliament, lobbying and negotiating in the French political milieu, seeking all the available ways to make sure the project was fulfilled, and supervising the entire educational process for the rest of his life. The official inauguration of the Romanian School in Fontenay-auxRoses took place on June 1, 1922. Since then, this locality and the school became the most important places for Romanian students in France. The functioning of the school facilitated the access of Romanian doctoral students in the humanities to the resources indispensable for study and research, while most of the Romanian historians with important works written during the interwar period benefited from scholarships there. The establishment of the communist regime destroyed this institution dedicated to Romanian education, first by closing its gates and then by selling the whole establishment. After the sale, in the years to come, the buildings of the institution were demolished. Instead, modern facilities were constructed. Thus, the spirit of the Romanian School in France disappeared. In 1997, in the Romanian Parliament a proposal was put
\end{abstract}


forward to revive this interwar project. However, this proposal was rejected due to the negative opinion of the specialized parliamentary commissions. After this event, the possibility was never discussed again.

Keywords: Romanian School in France, Nicolae Iorga, Fontenay-aux-Roses, Romanian culture, research scholarships

Legăturile culturale dintre Franța și România în perioada interbelică au fost într-un continuu trend ascendent, iar istoricul N. Iorga (1871-1940), un profund cunoscător al intelectualilor francezi, alături de care se formase, a fost un actor important al acestui proces. Sfârșitul Primului Război Mondial oferea continentului european împrejurări speciale pentru reclădirea legăturilor culturale internaționale. Istoricii V. Pârvan (1882-1927) și N. Iorga au considerat necesar să construiască la Roma și la Paris două instituții academice, denumite „școli”, care aveau ca principală atribuție de a-i adăposti pe tinerii români merituoși care absolviseră studiile de licență în România și care căutau institute de cercetare în care să se specializeze în domenii doctorale umaniste ${ }^{1}$. Tezele pregătite în urma acestor stagii bursiere urmau să fie susținute în România. În acest mod, în mediul celor două școli, au fost



Fotografia nr. I - Istoricul N. lorga (1871-1940), unul dintre prietenii cei mai apropiați ai geografului francez E. de Martonne.

(Sursă: Cele Trei Crișuri - Anale culturale, anul XVII, nr. 1-2, ianuarie-februarie 1936, Editura "Scrisul Românesc" din Craiova, Oradea, 1936, p. 23.) pregătite majoritatea studiilor istorice cu importanță în perioada interbelică.

Începând de la aceste certitudini, în cadrul prezentului articol încercăm să creionăm modul în care a fost creată și a funcționat Școala Română din Franța.

Urmărind exclusiv filonul francez al acestor demersuri meritorii, constatăm un context internațional româno-francez mai mult decât favorabil, întrucât, în luna iunie 1919, la București, a sosit o misiune universitară franceză, ce a semnat, la 15 iunie 1919, Convenția Poincaré-Angelescu² pentru sprijinirea

1 L. Nastasă, Itinerarii spre lumea savantă. Tineri din spațiul românesc la studii în străinătate (18641944) (Cluj-Napoca: Limes, 2006), 208.

2 Convenția a fost semnată de șeful misiunii universitare franceze, fizicianul francez Lucien Poincaré (1862-1920), și de profesorul Constantin I. Angelescu (1869-1948), ministrul instrucțiunii publice. 


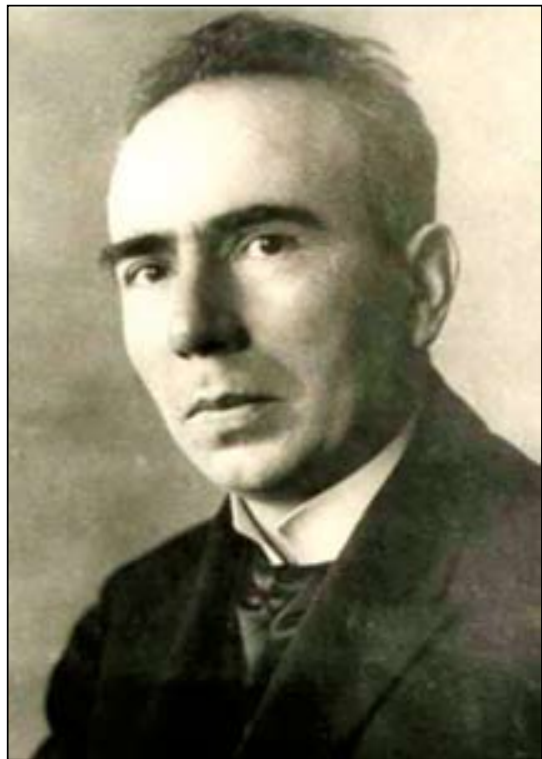

Fotografia nr. II - Istoricul V. Pârvan (1882-1927).

(Sursă: https://upload.wikimedia.org/ Vasile_Parvan) învățământului românesc. După dezbaterea ideilor în cercurile intelectuale apropiate de cei doi istorici fondatori, proiectul capătă o nuanță legislativă, iar cele două școli au fost întemeiate din punct de vedere legal printr-o lege specială votată de Parlamentul României în luna august 1920, legea fiind ulterior promulgată prin Decretul Regal nr. 4285 din 22 octombrie 1920³. Proiectul de inițiativă legislativă pentru cele două școli a fost elaborat de însuși N. Iorga, iar cele două instituții academice urmau să aibă secție de studii arheologice, secție de studii istorico-filologice și secție de arte frumoase ${ }^{4}$. Principala atribuție a acestor școli, conform proiectului legislativ inițial, era de a contribui „la strângerea legăturilor cu lumea apuseană pe tărâm științific, iar pe de altă parte să extindă contactele cu viața socială și cultura Occidentului”. Proiectul final al acestor școli prevedea, cu privire la organizarea internă a școlilor, că acestea vor avea alte secții în domenii complementare:

I. Secție pentru studiile de istorie și filologie a popoarelor romanice;

II. Secție pentru continuarea studiilor universitare de specialitate la acele discipline care nu se predau în România;

III. Secție pentru cultivarea artelor ${ }^{6}$.

Stagiile de specializare aveau durata de un an, existând posibilitatea ca acestea să fie prelungite la durata de doi ani, iar studenții beneficiari nu puteau fi decât cei recomandați de instituțiile naționale de învățământ superior ${ }^{7}$. Legea de înființare mai prevedea ca directorii acestor școli să fie numiți pe viață, sub pretextul prevenirii ca aceste instituții să intre sub influența jocurilor politice, însă situația a devenit arbitrară, cel puțin în cazul Școlii din

3 Nastasă, Itinerarii spre lumea savantă, 208.

4 I. Traia, „Viața și activitatea eruditului cărturar bănățean Ioachim Miloia”, în Administrație românească arădeană, Studii și comunicări din Banat-Crișana, Doru Sinaci, Emil Arbonie (coord.), vol. VI (Arad: Vasile Goldiș University Press, 2013), 292.

5 Ibidem, 292.

${ }^{6}$ Nastasă, Itinerarii spre lumea savantă, 208.

7 Ibidem, 208. 
Franța, unde director a fost numit N. Iorga ${ }^{8}$, cel care întreprinsese cele mai importante demersuri pentru această reușită. În aceeași lege de înființare, cu privire la Școala Română din Roma, s-a stabilit ca director al acesteia să fie istoricul și arheologul V. Pârvan ${ }^{9}$, personalitate recunoscută în științele umaniste la nivel internațional.

Aflat la Paris la începutul anului 1921, N. Iorga se va ocupa personal, alături de politicianul francez Léon Bérard (1876-1960), ministrul francez al învățământului din acea perioadă, de demersurile de înființare, iar la 18 ianuarie 1921 lua ființă din punct de vedere legislativ francez Școala Română din Paris, în orășelul

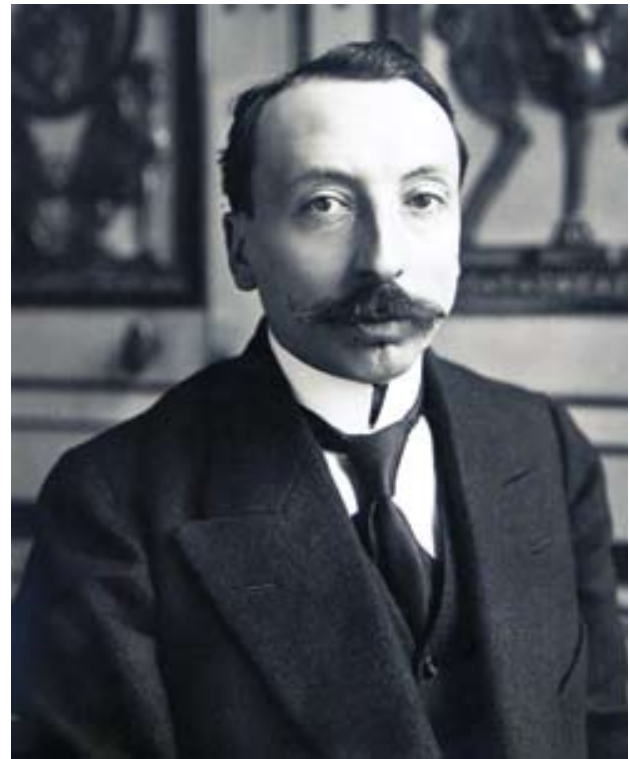

Fotografia nr. III - Politicianul francez Léon Bérard, ministrul instrucțiunii publice în 1919 și în 1921-1924.

(Sursă: https://en.wikipedia.org/wiki/ L\%C3\%A9on_B\%C3\%A9rard) pitoresc Fontenay-aux-Roses ${ }^{10}$, o suburbie a Parisului. Pentru această instituție N. Iorga achiziționează „pe seama statului român” un teren și o clădire în Fontenay-aux-Roses ${ }^{11}$. După înființarea legislativă, intrarea efectivă în activitate a instituției românești va avea loc în perioada următoare, procesul fiind unul anevoios și de durată. În toamna aceluiași an 1921, N. Iorga susține o conferință la Fontenay-aux-Roses ${ }^{12}$, acesta fiind primul act cultural românesc din liniștita localitate, însă pentru ca studenții români, cei pentru care fusese creată, să aibă acces la instituţie, va mai trece o perioadă de timp. Cu privire la aceste momente N. Iorga, a publicat, în revista Cele Trei Crişuri - Revistă de cultură din iulie 1923, un articol intitulat „Școala Românească din Fontenay-aux-Roses”, în cadrul căruia explica cum s-a ajuns la această realizare meritorie pentru cultura românească:

8 Ibidem, 208.

9 Traia, „Viața și activitatea eruditului cărturar bănățean Ioachim Miloia”, 293.

${ }^{10}$ Nicolae Iorga, Cugetări (București: Editura Tineretului, 1972), 298.

${ }^{11}$ A. Stănculescu-Bârda, N. Iorga - Concepția istorică (Craiova: Sitech, 2011), 31; A. StănculescuBârda, Nicolae Iorga, așa cum l-au cunoscut: Amintiri inedite adunate și prezentate (Bârda: Editura „Cuget Românesc”, 2012), 27.

${ }^{12}$ Stănculescu-Bârda, N. Iorga - Concepția istorică, 31; Stănculescu-Bârda, Nicolae Iorga, așa cum l-au cunoscut, 27. 


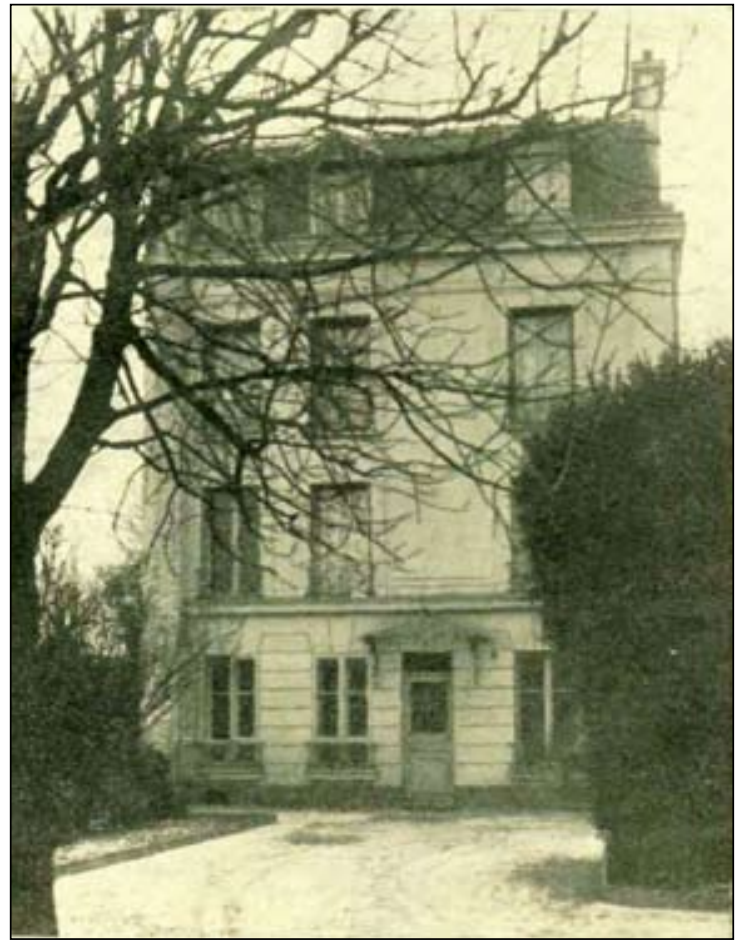

Fotografia nr. IV - Aripa Școlii Române în care locuiau membrii.

(Sursă: Ion Breazu, "Școala română din Paris", Boabe de grâu, anul I(1930), nr. 6: 332.)
„Printr'o lege votată în 1921, după propunerea mea, s'au înființat pentru strângerea relațiilor cu latinitatea apuseană două „școli” românești, pentru cercetări în arhive și bibliotecei, precum și pentru contactul cu cultura și viața socială a Occidentului cu aceeași rasă cu noi, în Franța și în Italia”'13.

Locul ales pentru așezarea acestei instituții a fost imobilul cu numărul 48 de pe strada Châtaigniers ${ }^{14}$ din Fontenay-aux-Roses, la aproximativ $5 \mathrm{~km}$ de Paris, într-un imobil achiziționat de N. Iorga în contul statului român ${ }^{15}$, aşa cum menționam anterior. Se pare că istoricul român a ales acest loc după ce a urmat sfatul prietenului

său, istoricul francez Ferdinand Lot (1866-1952), care locuia în același orășel, pe strada Boucicaut, la imobilul cu nr. 53 ${ }^{16}$. Ziarul Le Temps din 3 iulie 1922 consemna inaugurarea Școlii Românești și amintea contextul în care avea loc acest eveniment. Conform publicației, scopul noii instituţii academice era de „a consolida și dezvolta legăturile intelectuale deja existente între România și Franța și pentru a permite viitorilor maeștri ai învățământului superior din România să se angajeze în cercetări originale în instituțiile de înaltă cultură franceză...”17.

\footnotetext{
${ }^{13}$ Stănculescu-Bârda, N. Iorga - Concepția istorică, 31; Stănculescu-Bârda, Nicolae Iorga, așa cum l-au cunoscut, 27.

${ }^{14}$ A se vedea: „La Croix pour le sous-directeur de l'École Roumaine ? (1923)”, L'Archive de la Quinzaine, 30 mars-11 avril 2015, https://www.fontenay-aux-roses.fr/fileadmin/fontenay/ MEDIA/decouvrir_la_ville/histoire/Publications/Quinzaine/281-_La_Croix_pour_le_sous-directeur_de_1_Ecole_Roumaine_1923_.pdf (accesat la 10 noiembrie 2018).

${ }^{15}$ Nastasă, Itinerarii spre lumea savantă, 208.

${ }^{16}$ „La Croix pour le sous-directeur de l'École Roumaine ? (1923)”

${ }^{17}$ Le Temps, anul 62 (nr. 22.247, 3 iulie 1922), 3.
} 
Aceeași publicație mai menționa faptul că Școala Românească din Franța „a fost creată (...) ca o imitație a școlilor franceze de la Roma și Atena, la iniţiativa dr. N. Iorga, profesor la Universitatea din București...”18.

Analizând în profunzime semnificația locului ales de mentorul instituției, constatăm că aceasta a fost luată în calculul final de N. Iorga, în calitatea sa de prim director al Școlii și de cumpărător al terenului ${ }^{19}$, în principal, pentru a evita tentaţiile neintelectuale ale Parisului ${ }^{20}$. Se pare că, tot la propunerea acestuia, în cadrul Școlii, se impuneau o serie de reguli riguroase în încercarea de a avea un minim control asupra tinerilor români sosiți pentru stagii academice, iar dintre acestea pot fi menţionate sumar următoarele: servirea micului dejun și a cinei la sediul școlii, prezența obligatorie pe timpul nopții în cadrul școlii, interdicția de a aduce musafiri în camere și interdicția de a locui împreună cu soțiile ${ }^{21}$. Regulamentul de funcționare al celor două școli a fost publicat în Monitorul Oficial al Regatului României, nr. 105 din 13 august 1921, și mai prevedea: „...cele două instituții au caracterul unui «internat academic», în care disciplina trebuia să fie foarte strictă. Școala din Franța acorda prioritate cercetărilor de arhivă și în biblioteci, cea din Roma se axa în principal pe arheologie. Fiecare din cele patru universități putea recomanda câte doi membri pe an pentru fiecare Școală. Numărul de membri a fost fixat la 10 pentru fiecare din ele, în doar câteva cazuri urcând la 11-12”22. Aceste reguli și restricții riguroase, precum și distanţa relativ mare până la bibliotecile și instituţiile de învățământ superior pariziene au generat numeroase nemulțumiri în rândul bursierilor. Dacă analizăm toate aceste aspecte, inclusiv bursa acordată de stat, redusă din punct de vedere financiar pentru necesitățile și cheltuielile Parisului, constatăm că un număr relativ mare de viitori universitari români au beneficiat de burse în cadrul instituţiei ${ }^{23}$, în ciuda costurilor destul de ridicate pentru această perioadă. Explicațiile oferite de însuși N. Iorga cu privire la aceste aspecte, la un an de funcționare efectivă a școlii, publicate în articolul „Școala Românească din Fontenay-aux-Roses”, sunt mai mult decât lămuritoare cu privire la anumite aspecte:

„Școala din Franța, a cării conducere o am, n'a fost așezată în Paris chiar, ci pentru liniștea studiului în mica localitate, de o încântătoare poezie a naturii Fontenayaux-Roses, care-și spune în nume chiar belșugul florilor. La o distanță foarte mică de capitală, cam o jumătate de ceas cu trenul sau cu tramvaiul până la Sorbona, membrii școlii au toate plăcerile aerului liber, ale mediului de frumusețe și sănătate.

\footnotetext{
${ }^{18}$ Ibidem, 3.

${ }^{19}$ Stănculescu-Bârda, N. Iorga - Concepția istorică, 31; Stănculescu-Bârda, Nicolae Iorga, așa cum l-au cunoscut, 27.

${ }^{20}$ Nastasă, Itinerarii spre lumea savantă, 208.

${ }^{21}$ Ibidem, 209.

${ }^{22}$ Ibidem, 208 (nota 161).

${ }^{23}$ Ibidem, 209.
} 


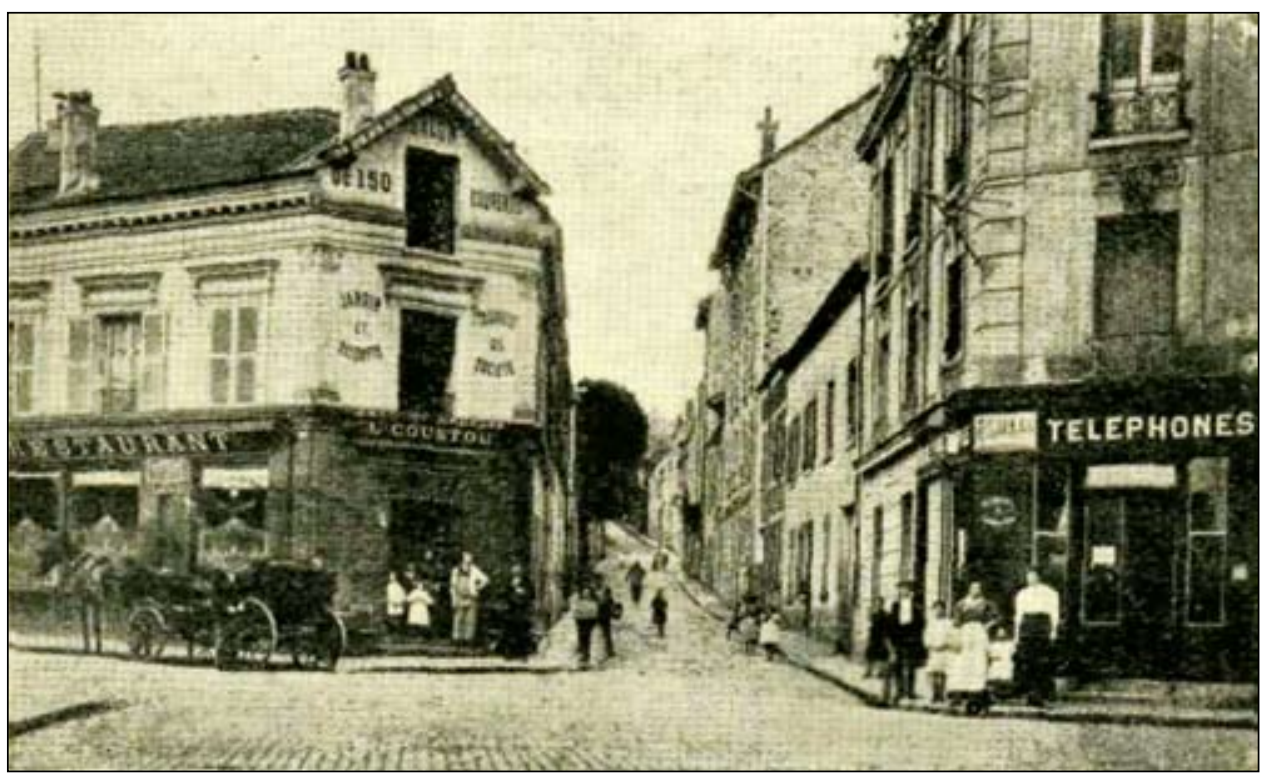

Fotografia nr. V - Fontenay-aux-Roses. Rue des Châtaigniers, strada în continuarea căreia se găsea Școala Română din Franța.

(Sursă: Breazu, „Școala română din Paris", 333.)

Localul, care e proprietatea Statului român încă de la început, se compune dintr'un mare corp de clădire cu douăsprezece odăi în trei rânduri, din altul în față, cu aproape același număr de încăperi, dintr'un pavilion destinat Muzeului românesc, din două grădini și o destul de mare livadă. E așezat sus, lângă șoseaua care înconjoară fortificațiile și care duce, prin cea mai abundentă verdeață, într'o liniște ideală, deși la picioare e un întreg oraș, cu toate avantagiile pe care le poate oferi" ${ }^{24}$.

Școala Română din Franța venea pe filonul inexistenței unor instituții specifice care să se ocupe direct de aspectele academice dintre România și Franța. Astfel, în anul 1922, în data de 1 iulie $^{25}$, după o pregătire anterioară de doi ani, se inaugurează, cu mare fast, École roumaine en France. Creatorul instituției educaționale, istoricul N. Iorga, oscilase între această denumire și cea de Institutul Român din Franța ${ }^{26}$, iar cu privire la inaugurarea din data de 1 iulie acesta nota în propriile memorii:

„Inaugurarea, mult zăbovită, din cauza deszicerilor ministrului Bérard ${ }^{27}$ (în războiu cu Universitatea), a Școlii noastre. Asistă Appell, care vorbește și căruia-i

\footnotetext{
${ }^{24}$ Iorga, „Școala Românească din Fontenay-aux-Roses”, 103.

${ }^{25}$ Nastasă, Itinerarii spre lumea savantă, 208.

${ }^{26}$ Pentru consultarea unui studiu avizat referitor la această problematică istorică, a se vedea: Petre Țurlea, Scoala Română din Franța (București: Editura Academiei Române, 1994), 17.

${ }^{27}$ Istoricul român se referă la politicianul și diplomatul francez Léon Bérard (1876-1960).
} 


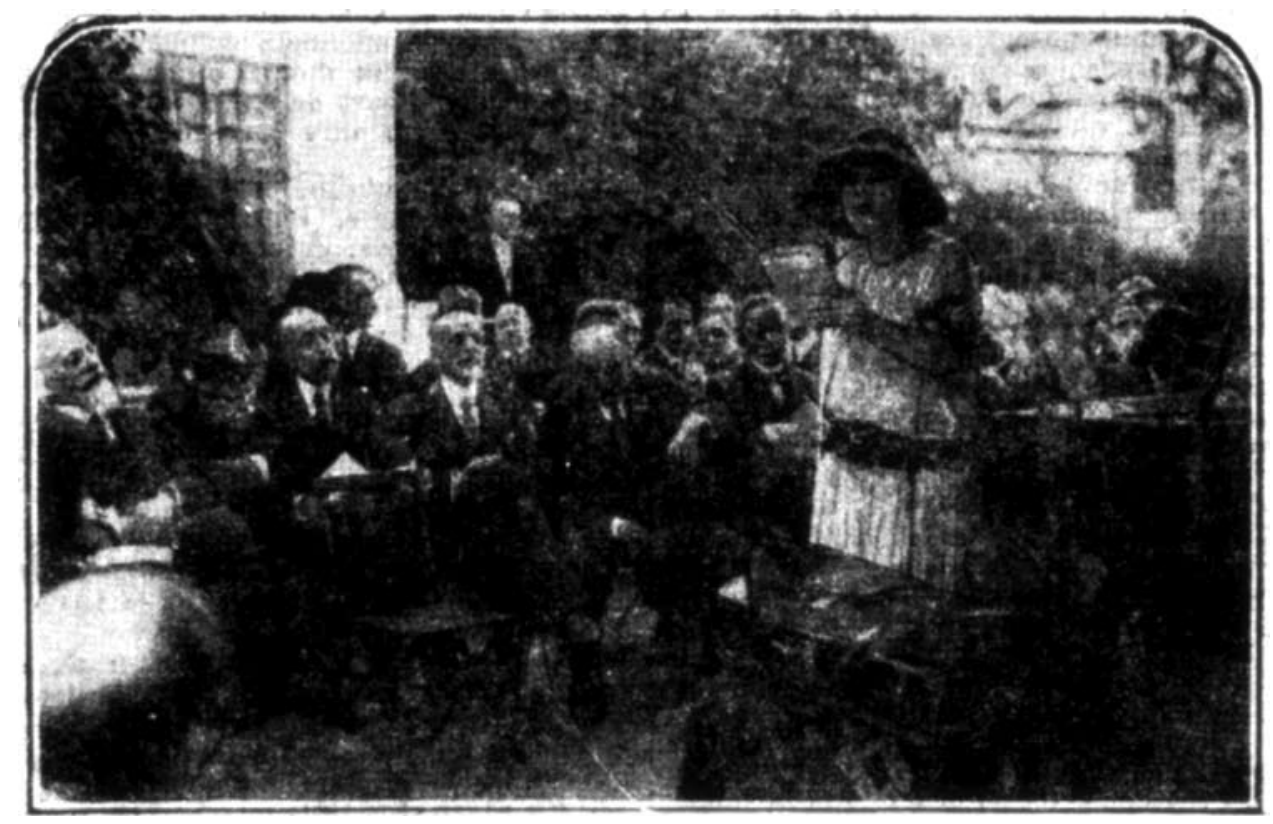

Fotografia nr. VI - Domnișoara Maria Ventura (1888-1954), actriță și membră a Comédie Française, rostește un poem cu ocazia inaugurării Școlii Române la Fontenay-aux-Roses. (Aceasta a mai fost cunoscută sub numele complet de Aristida Maria Ventura, fiind născută la București, la 14 iulie 1888.)

(Sursă: Le Petit Journal - Edition de Paris, nr. 21.717, 2 iulie 1922: 1.)

răspunde Antonescu (sunt silit să adaug câteva cuvinte despre valoarea politică a înființării școlii), Brunot, Diehl, de Martonne, Glotz, deputatul Lorin, profesorul Brunel. Mă bucură în deosebi venirea vechiului mieu profesor Bémont, pe care 1-am cercetat acum două zile în locuința-i înflorită de la Croissy-sur-Seine. Se recitează (d-ra Ventura emoționează adânc prin imnul d-nei de Noailles către Ilede-France și comorile ei)"28.

Festivitățile din data de 1 iulie 1922, desfășurate sub îndrumarea directă a lui N. Iorga ${ }^{29}$ au beneficiat de prezența unui număr important de personalități ale mediului academic francez, între care îi amintim: profesorul Paul Appell (1855-1930) - rector al Universităţii din Paris, Ferdinand Brunot (1860-1938) - decan al Facultății de Litere, Charles Diehl (1859-1944) - istoric de artă, Em. de Martonne (1873-1955) - renumitul geograf specializat în problemele geografice românești ${ }^{30}$, G. Glotz (1862-1935), Clovis Brunel (1884-1971),

${ }^{28}$ N. Iorga, Memorii. Vol. III. Tristețea și sfârșitul unei domnii (București: Editura „Naționala” S. Ciornei, 1939), 309.

${ }^{29}$ Dan Berindei, Românii și Europa în perioadele premodernă și modernă, (București: Editura Enciclopedică, 1997), 410; A se vedea, de asemenea: Iorga, Cugetări, 298.

${ }^{30}$ Jean-Yves Conrad, „Nicolae Iorga și elevii Școlii Române din Paris, la Fontenay-aux-Roses”, Biblioteca Bucureștilor, Anul VI, 2003 - I: 34. 
Ch. Bemont (1848-1939) și actrița cu origini românești Maria Ventura (18881954) ${ }^{31}$. Din partea statului român au fost prezenți la eveniment, în calitate de reprezentanți oficiali, ambasadorul Victor Antonescu (1871-1947), ministrul României la Paris în această perioadă ${ }^{32}$ și unul dintre consilierii Legației Române din Franța. Înainte de momentul festiv, în data de 2 mai 1922, istoricul C. Marinescu (1891-1982) îi va trimite o scrisoare mentorului său, N. Iorga, din localitatea Fontenay-aux-Roses, prezentându-i discuţiile avute de acesta cu profesorii Universității Sorbona cu privire la viitoarea sosire a istoricului român la Paris pentru a susține o serie de conferințe. Conform scrisorii, profesorul M. Roques (1875-1961) a remarcat după această discuție că „invitaţiunea trimisă d(umnea)voastră echivalează cu un schimb de profesori între România și Franța, d(omnul)1 E. de Martonne făcând începutul” ${ }^{33}$. Publicația Le Temps din 3 iulie 1922 realizează o descriere fidelă a desfășurării evenimentului. Astfel, aflăm că rectorul Universității din Paris, profesorul P. Appell, a susținut un discurs în calitate de reprezentant al Ministerului Educației Naționale. În cadrul cuvântării sale, rectorul Sorbonei a făcut un adevărat elogiu acțiunii întreprinse de istoricul român și a promis concursul direct al universității pe care o conduce pentru crearea noului Institut de Studii Franco-Române, ce va funcționa în cadrul Școlii Române din Franța, iar la aceste afirmații asistența a răspuns cu un puternic ropot de aplauze. Discursul susținut de rectorul P. Appell a fost urmat de un discurs al diplomatului V. Antonescu, ministrul plenipotențiar al României în Franța, cel care, în numele guvernului român, le mulțumește și îi felicită pe profesorii N. Iorga și P. Appel pentru dedicarea de care au dat dovadă pentru acest rezultat academic ${ }^{34}$. Conform aceleiași publicații Le Temps din 3 iulie 1922, manifestația se încheie printr-un discurs elocvent rostit de însuși creatorul noii instituții, cel care menționa „tot ceea ce cultura franceză a dat deja României. De asemenea, el a arătat cum va funcționa școala românească, care va include o duzină de rezidenți, desemnați de diferite universități din România, dintre absolvenții și doctorii de litere, filologi, istorici și artiști.

${ }^{31}$ B. Theodorescu, Nicolae Iorga (1871-1940). Biobibliografie (București: Editura Științifică și Enciclopedică/Editura Militară, 1976), 81; a se vedea, de asemenea: Stănculescu-Bârda, N. Iorga - Concepția istorică, 32 și Stănculescu-Bârda, Nicolae Iorga, așa cum l-au cunoscut, 28.

32 Țurlea, Scoala română din Franța, 17.

${ }^{33}$ Profesorul francez se referă la semestrul predat de geograful francez Emmanuel de Martonne la Universitatea din Cluj în anul 1921, în calitate de profesor aflat sub auspiciile misiunii universitare franceze. A se vedea: Nicolae Iorga și Universitatea din Cluj. Corespondență (1919-1940) (București: Academia Română, Fundația Naţională pentru Știință și Artă și Institutul de Istorie şi Teorie Literară „G. Călinescu”, 2005), 85.

${ }^{34}$ Le Temps, anul 62, nr. 22.247, 3 iulie 1922, 3. 
Un festival artistic a urmat acestui eveniment frumos" 35 .

A doua zi, 2 iulie 1922, a avut loc lansarea oficială a activității Școlii, iar în acest sens s-a organizat o serbare pentru locuitorii localității Fontenay-aux-Roses. Aceștia, pentru a-și manifesta simpatia față de România, au cerut să fie intonat imnul național al României în cadrul festivității ${ }^{36}$, fapt menționat și în memoriile lui N. Iorga ${ }^{37}$. Juristul Victor Ianculescu a fost cel care s-a ocupat de coordonarea instituţiei, urmând directi-

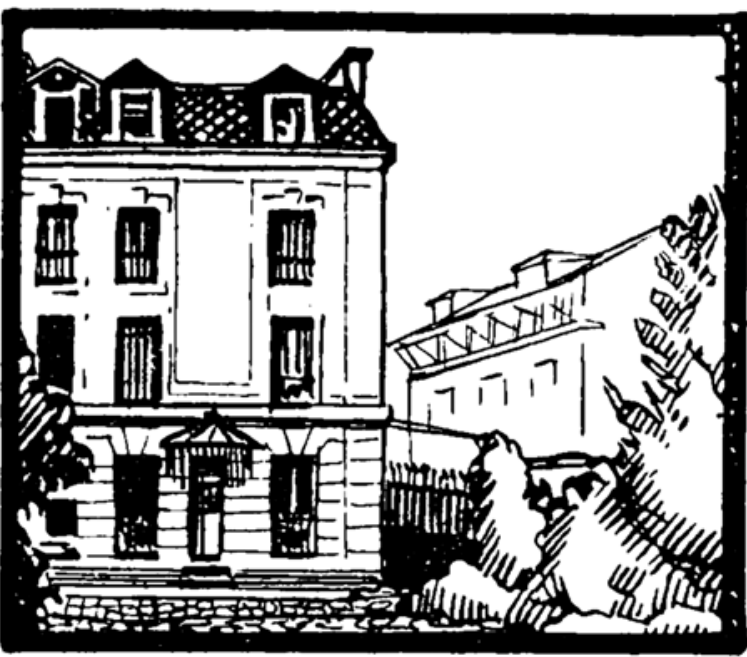

Fotografia nr. VII - Desen în creion al Școlii Române din Fontenay-aux-Roses.

(Sursă: Septime Gorceix, "Les Amitiés franco-roumaines. L'École franco-roumaine de Fontenay-aux-Roses", Les Annales politiques et littéraires - Revue universelle, illustrée hebdomadaire, nr. 2122, 24 februarie 1924, www.gallica.fr., accesat la 19 decembrie 2018.) vele lui N. Iorga, iar într-o scrisoare trimisă istoricului român, în data de 4 iulie 1922, consemna modul în care „Fontenay-ul a devenit cel mai filoromân oraș din Franța” ${ }^{38}$. În anul 1923, N. Iorga analiza, în articolul „Școala Românească din Fontenay-aux-Roses”, modul în care V. Ianculescu s-a ocupat de coordonarea instituţiei românești, menționând:

„Îngrijirea exemplară a dlui sub. director Victor Ianculescu, foarte bine cunoscut in cele mai distinse cercuri franceze, face ca instalația noastră să poată fi privită ca model pentru asemenea așezăminte.

Acolo dl. C. Marinescu a făcut lucrări de istorie care i-au asigurat stima profesorilor francezi, acolo dl. Alexandru Rosetti și-a redactat articolele pentru marea revistă de filologie «Romania», acolo dl. N. Constantinescu și-a orânduit notele pentru chestia țărănească în Imperiul bizantin, acolo dl. Sanciuc, Lambrino și Munteanu au cultivat științele filologice și dl. Virgil Bogdan și-a pregătit studiile de filosofie; acolo și-a zugrăvit pânzele pictorul de mare talent care e Catul Bogdan. Am găsduit și pe un tânăr filolog sas dl. Folberth. O bibliotecă necontenit adăugită stă la îndemâna cercetătorilor.

\footnotetext{
${ }^{35}$ Ibidem, 3.

${ }^{36}$ Țurlea, Scoala română din Franța, 17.

${ }^{37}$ Iorga, Memorii. Vol. III. Tristețea și sfârșitul unei domnii, 309.

${ }^{38}$ Țurlea, Scoala română din Franța, 17.
} 


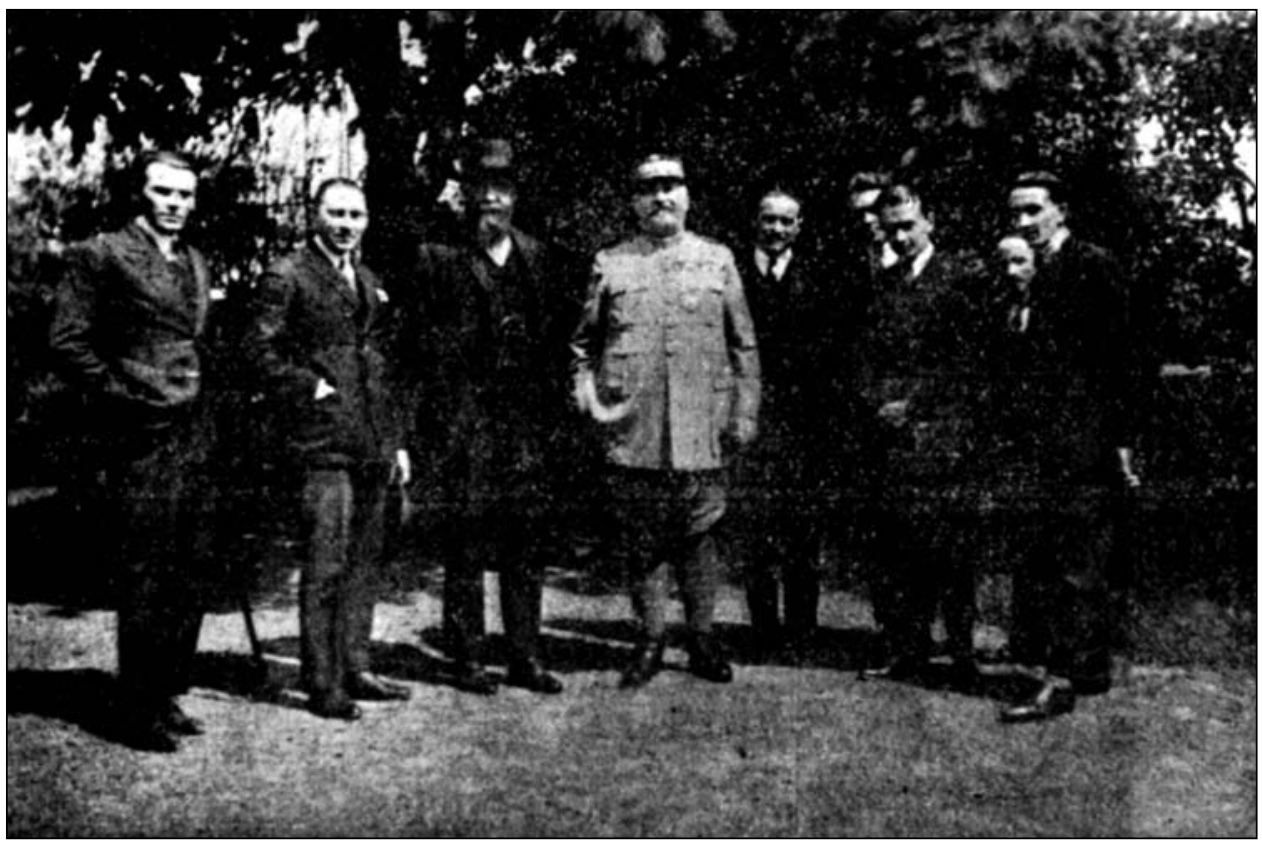

Fotografia nr. VIII - Istoricul N. lorga, generalul H. Berthelot, conducerea instituției educaționale și câțiva studenți la Școala Română din Fontenay-aux-Roses în anul 1923.

(Sursă: N. Iorga, "Școala Românească din Fontenay-aux-Roses", Cele Trei Crișuri - Revistă de cultură, anul IV, nr. VII, iulie 1923: 103.)

S'au primit multe vizite plăcute și unele de la reprezentanți iluștri ai nației prietene. Fototipia de față - reprodusă anterior și în acest volum - înfățişează între noi pe generalul Berthelot, atâta timp unul dintre sprijinitorii speranțelor noastre ${ }^{\prime 39}$ (a se vedea foto $\mathrm{nr}$. VIII).

Analizând în profunzime modul de funcționare al Școlii Române din Paris, sub coordonarea lui V. Ianculescu, constatăm că aceasta a cunoscut o evoluţie fulminantă. Ianculescu a reușit să transforme o casă simplă cu două etaje într-o veritabilă unitate educațională: 12 camere, câte una pentru fiecare student, o sală de studiu, o bibliotecă de peste 3000 de volume, un atelier de artă, săli de expoziție (pentru arta românească și pentru arta populară). Pentru toate aceste merite, directorul instituției românești a fost propus de autoritățile franceze în anul 1923 pentru decorare cu Legiunea de Onoare în grad de Cavaler.

Principalele rezultate obținute în urma cercetărilor din Franța de către bursierii români ai Școlii din Fontenay-aux-Roses vor fi publicate, începând cu anul 1923, în revista anuală Mélanges de l'École roumaine en France ${ }^{40}$. Dacă analizăm funcționarea concretă a instituției din prima perioadă a acesteia, consta-

\footnotetext{
${ }^{39}$ Iorga, Școala Românească din Fontenay-aux-Roses, 103.

${ }^{40}$ Nastasă, Itinerarii spre lumea savantă, 209.
} 


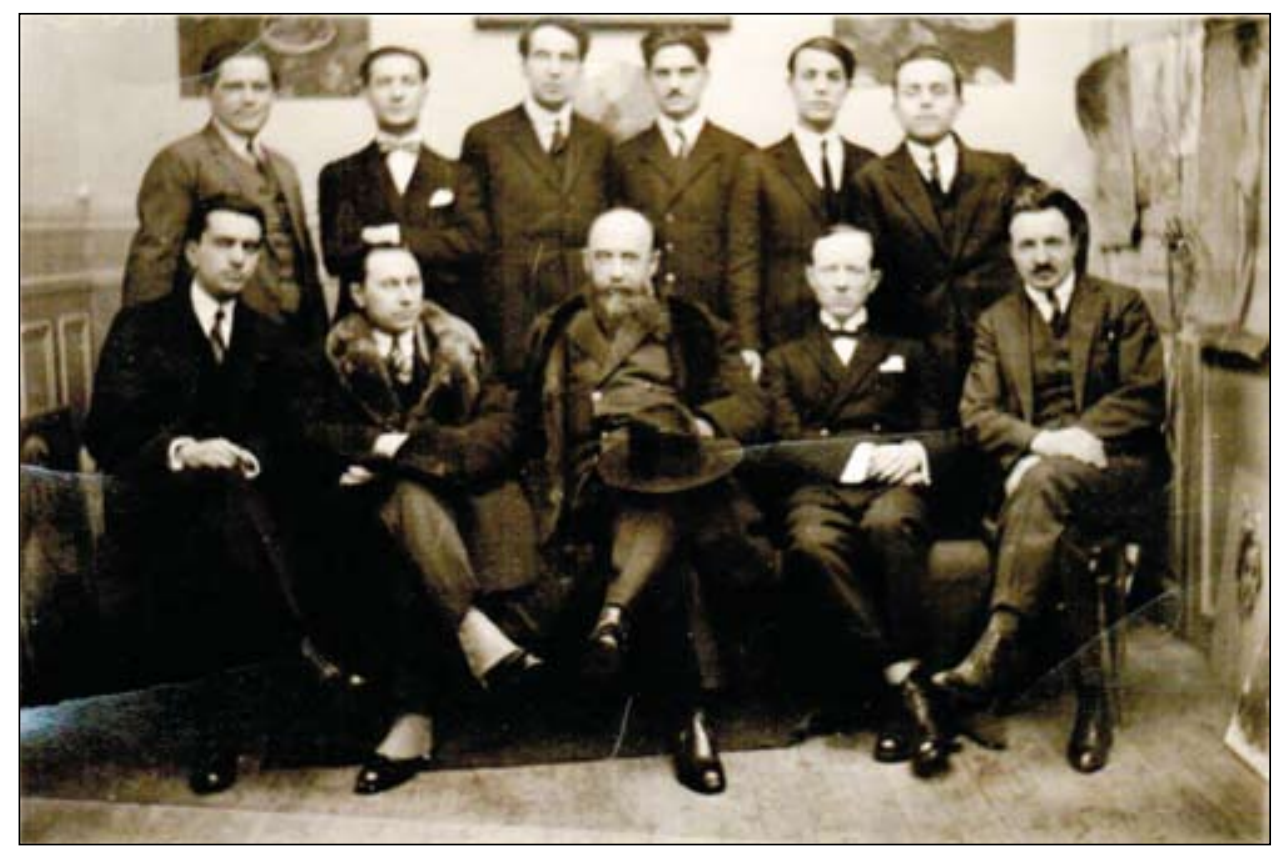

Fotografia nr. IX - Școala Română de la Paris, Fontenay-aux-Roses, în anul 1925. Rândul de jos, de la stânga la dreapta: Ion Chinezu, Ion lanculescu, Nicolae lorga, I. M. Rașcu, Richard Hette. Rândul de sus, de la stânga la dreapta: Bazil Munteanu, Dumitru Murărașu, Petre P. Panaitescu, Vlad Bănățeanu, Vasile Băncilă, Dan Băjenaru.

(Sursă: Elena Ilie, „Vasile Băncilă și P. P. Panaitescu. Pagini de corespondență”, Acta Musei Tutovensis, nr. 1, 2015: 46.)

tăm că aceasta găzduia anual 12 bursieri, exclusiv bărbaţi, până în 1927, care dețineau licențe în filologie sau istorie susținute în România, la una dintre cele patru universități: București, Iași, Cluj și Cernăuți, plus un pictor sau sculptor, care era ales dintre laureații Școlii de Artă din București sau Iași ${ }^{41}$. Aceștia erau obligați să susțină anual o cercetare științifică (istoricii și filologii) sau să prezinte o operă artistică (artiștii plastici), iar ultima parte din acest proces de verificare a activității bursierilor era cea a susținerii unui memoriu, în fața directorului școlii, cu privire la întreaga activitate întreprinsă în Franța ${ }^{42}$. Întrucât veniturile bursierilor erau insuficiente, aşa cum menționam anterior, și având în vedere costurile vieții de zi cu zi din Franța, statul francez a acordat burse de 800 de franci, la care se adăugau 300 de franci oferiți de școală ${ }^{43}$. În anul 1936, N. Iorga rememora, în volumul „S,coala nouă” de istorie: O lămurire definitivă,

\footnotetext{
${ }^{41}$ Jean-Yves Conrad, Paris, capitala... României. Ghid al plimbărilor insolite pe urmele românilor celebri din Paris, trad. Elisabeta Balint (Iași: Junimea, 2006), 318.

${ }^{42}$ Ibidem, 318.

${ }^{43}$ Ibidem, 318.
} 
momentul în care a fost creată și modul în care funcționa Școala Română din Fontenay-aux-Roses, raportându-se la foștii săi studenți, cu care nu se afla în cele mai apropiate legături după trecerea anilor:

„La școala, pe care eu am întemeiat-o prin proiectul de lege depus de mine, de la Fontenay-aux-Roses, ca și pe cea din Roma, am căutat prin toată influența pe care o aveam într'un Consiliu de Facultate unde, din causa jignirilor nesancționate, nu mai pot călca de ani de zile, și nu fără pagubă pentru Facultate, ajunsă în mîinile unei clice de caracter vădit politic, să-i fac a ajunge la aceste școli menite să puie pe absolvenții Universităților noastre în legătură cu lumea științifică și cu întreaga cultură din Franța și din Italia. În acea școală pe care o conduceam eu, puind la îndemîna membrilor ei prețioasele legături personale pe care le pot avea ca profesor agreat la Sorbona și ca unul din puținii membri asociați ai Institutului de Franța, am avut o deosebită grijă și, în ce priveșle sănătatea zdruncinată a unora dintr'înșii, pentru aceia cărora credeam că li voiu fi lăsat sentimente care mă ilusionam că-mi sînt datorite. (...)

Biblioteca pe care, cu ajutorul atît de harnicului conducător permanent, ca subdirector, al școlii, d. Victor Ianculescu, am adunat-o în frumoasa clădire cumpărată de mine" ${ }^{34}$.

Ultima perioadă din istoria Școlii Române din Franța a fost nefastă, fiind marcată de evenimentele lugubre ce s-au abătut asupra continentului european. După ocuparea Parisului de către trupele germane în ziua de 14 iunie 1940, Școala Română din Fontenay-aux-Roses își va înceta activitatea. Ulterior, în luna mai 1941, printr-un nou Decret-lege de reorganizare a celor două școli, Școala reintră în unele dintre atribuțiile sale și sunt numiți noii directori: Scarlat Lambrino (1891-1964) - Școala Română din Roma și C. Marinescu (18911982) - Școala Română din Paris ${ }^{45}$. Se pare că fostul director al instituției, V. Ianculescu, a rămas în cadrul Școlii până în $1942^{46}$, însă fără a avea o funcție în organigrama internă. Condițiile de funcționare ale Școlii sunt vitregite de vremurile în care își desfășura activitatea, studenții fiind în imposibilitatea de a ajunge în Franța din cauza războiului, dar și din cauza obligației de a face dovada că „au luptat cel puțin 6 luni pe frontul de Răsărit în actualul război”"47. Acest fapt îl va face pe C. Marinescu să solicite Academiei Române să-i recunoască drept bursieri temporari pe nouă dintre tinerii români aflați la studii la Paris $^{48}$. În anul 1947 apar alte probleme în funcționarea Școlii, iar, ulterior, în

\footnotetext{
${ }^{44}$ N. Iorga, „Școala nouă” de istorie - O lămurire definitivă (Vălenii-de-Munte: Tipografia „Datina Românească”, 1936), 5.

${ }^{45}$ Nastasă, Itinerarii spre lumea savantă, 209.

${ }^{46}$ A se vedea „La Croix pour le sous-directeur de l'École Roumaine ? (1923)”.

47 Veronica Turcuș, Șerban Turcuș, Între cultură, șantaj și spionaj. Academia din Romania la crepuscul (1947-1955). Studiu și documente, (Cluj-Napoca: Editura Școala Ardeleană, 2017), 8-9.

${ }^{48}$ Ibidem, 9.
} 
anul 1948, după ce puterea comunistă reușește să preia toate pârghiile de conducere ale României și are loc instaurarea Cortinei de Fier, prin noua Lege a învățământului, cele două școli au fost desființate oficial ${ }^{49}$, sub semnătura Anei Pauker (1893-1960). Sub această lege intră și destinul istoricului C. Marinescu, ultimul director al Școlii Române din Franța, acesta fiind demis din funcția de conducere, exclus din Academia Română, iar în acest context alege să se stabilească în Occident pentru întreaga viaţă ${ }^{50}$.

Negura comunismului a afectat iremediabil soarta instituției din capitala Franței, aceasta fiind marcată de incertitudine în anii următori. În anul $1960^{51}$ sau 1962, clădirea a fost vândută de statul român comunist Companiei Imobiliare Val Content ${ }^{52}$, iar în anii următori clădirea istorică a fost dărâmată ${ }^{53}$, pe terenul respectiv construindu-se blocuri de locuințe ${ }^{54}$. Astăzi nimic nu amintește de locul în care în perioada interbelică se pregăteau generațiile de tineri intelectuali români, iar numele străzii a fost schimbat din „Rue Châtaigniers” în „Rue Jean Lavaud"5s. Conform istoricului L. Nastasă, în perioada actuală, în zona Școlii Române din Fontenay-aux-Roses și-a găsit locul o importantă arteră de circulație ${ }^{56}$.

După căderea comunismului, a existat o tentativă de revitalizare a spiritului instituției. Astfel, în data de 2 aprilie 1997, prin adresa nr. 31, Biroul Permanent al Camerei Deputaților, în conformitate cu art. 86 din Regulamentul Camerei Deputaților, a sesizat pentru examinare și avizare Comisia pentru Buget, Finanțe și Bănci cu privire la propunerea legislativă de reînființare a Școlii Române din Franța ${ }^{57}$. Avizul negativ al Comisiei pentru Buget, Finanțe și Bănci asupra propunerii legislative privind reînființarea Scolii Române din Franța a fost emis în data de 22 aprilie 1997. Acesta a fost dat cu majoritatea voturilor, întrucât, în viziunea membrilor comisiei de analiză, din expunerea de motive și din propunerea legislativă nu rezultau cu claritate și fără echivoc următoarele elemente: „Ce rol ar fi urmat să aibă viitoarea instituție - unitate de studiu (institut

${ }^{49}$ Nastasă, Itinerarii spre lumea savantă, 209.

${ }^{50}$ Turcuș și Turcuș, Între cultură, șantaj și spionaj, 9-n., 5.

${ }^{51}$ Virgil Cândea, Mărturii românești peste hotare. Creații românești și izvoare despre români în colecții din străinătate. Vol. II. Finlanda-Grecia, ed. I. Feodorov (București: Editura Biblioteca Bucureștilor, 2011), 12.

${ }^{52}$ A se vedea: „La Croix pour le sous-directeur de l’École Roumaine ? (1923)”.

${ }^{53}$ Nastasă, Itinerarii spre lumea savantă, 208-n., 162.

${ }^{54}$ Cândea, Mărturii românești peste hotare, 12.

55 „La Croix pour le sous-directeur de l'École Roumaine ? (1923)”.

${ }^{56}$ Nastasă, Itinerarii spre lumea savantă, 208-n., 162.

${ }^{57}$ A se vedea documentul: „Avizul asupra propunerii legislative privind reînființarea Școlii Române din Franța”, Parlamentul României - Camera Deputaților - Comisia pentru Buget, Finanțe și Bănci, nr. XXXVI/2/214 din 22.04.1997, 1. Accesat 19 noiembrie 2018, http://www.cdep.ro/ comisii/buget/pdf/1997/av031.pdf. 
sau bibliotecă) sau unitate de cazare (internat sau cămin)?”; „Care era relația dintre universitățile românești ce urmau să selecteze studenții pentru burse și instituțiile de învătământ franceze unde aceștia urmau să studieze?”; „Bursele de studiu vor fi oferite de universitățile românești sau de cele franceze?”; „Instituția va avea caracter universitar sau postuniversitar?”; „Ce recunoaștere vor avea diplomele obținute după stagiile efectuate la instituția de învățământ?”; „Cine anume va suporta cheltuielile de funcționare pentru această instituție și salariile personalului, luându-se în calcul că Ministerul Învățământului și Academia Română nu au capitalul bugetar pentru acest gen de cheltuieli în afara țării?” În finalul avizului negativ se constata lipsa unui imobil unde ar putea funcționa instituția, întrucât fosta clădire a fost vândută după desființarea Școlii Române din Franța în anul $1948^{58}$. După această propunere lăudabilă, o astfel de propunere nu a mai fost luată în calcul de niciun alt membru al legislativului român și, astfel, a încetat o parte din spiritul românesc din Franța.

Şcoala Română din Fontenay-aux-Roses a facilitat formarea majorității istoricilor români din perioada interbelică, iar studiile remarcabile ale acestora au fost documentate sub egida acestei instituții. În România actuală, idealul generației de istorici români ar putea fi revitalizarea acestui lăudabil proiect interbelic. Memoria acestei instituții merită să fie adusă în prim-planul vieții culturale româno-franceze și poate că anii sau deceniile următoare vor găsi oamenii de stat capabili să refacă din cenușă această Pasăre Phoenix a culturii românești.

\section{Rezumat:}

Începutul secolului al XX-lea a fost puternic marcat de Primul Război Mondial. Între rezultatele neprevăzute de după acesta constatăm o creștere exponențială a relațiilor culturale dintre state din aceleași tabere combatante. Dacă analizăm, în mod expres, relațiile culturale româno-franceze din această perspectivă, constatăm că avem de a face cu un adevărat exemplu de colaborare culturală pe continentul european, întrucât rar au mai existat alte exemple de conlucrare atât de pronunțate. Primul pas concret al acestui proces lăudabil a fost semnarea, la 15 iunie 1919, la București, a Convenției educaţionale Poincaré-Angelescu, convenție prin care statul francez se oferea să își ofere suportul pentru consolidarea învățământului românesc, în special în noile provincii ce intrau în componența statului român. Astfel, lua naștere la București misiunea universitară franceză, ca entitate de sine stătătoare, izvorătă din această convenție, iar ulterior, în anul 1924, era înființat Institutul Francez de Înalte Studii. Prin cele două acțiuni concrete, statul

${ }^{58}$ Ibidem, 1. 
francez prelua inițiativa și oferea suportul său promis pentru „sora latină din estul Europei”. În aceeaşi perioadă, acțiunile Regatului României în acest sens au fost mult mai anevoioase, fiind nevoie de o inițiativă privată, a istoricului N. Iorga, pentru ca la București să se discute de înființarea școlilor române din Franța și Italia. În privința Școlii Române din Franța, N. Iorga se va ocupa de toate demersurile pentru a vedea fiabilă această instituție: alegând o clădire în pitoreasca localitate din suburbia Parisului - Fontenay-aux-Roses, pe care o va cumpăra în numele statului român, propunând legea specială în Parlamentul României, intervenind în mediul politic francez, pe toate căile disponibile, pentru a vedea proiectul realizat și supervizând această entitate educațională întreaga sa viață. Inaugurarea oficială a Școlii Române din Fontenay-aux-Roses a avut loc la 1 iunie 1922, iar din acel moment localitatea și şcoala au devenit cele mai importante locuri ale studenților români din Franța. Funcționarea școlii a facilitat accesul doctoranzilor români în domeniile umaniste la resurse livrești indispensabile pentru studiu şi creație, iar majoritatea istoricilor români cu studii importante în perioada interbelică au beneficiat de burse la Școala Română. Autoritățile comuniste au distrus acest loc dedicat învățământului românesc, întâi prin închiderea porților și, ulterior, prin vinderea stabilimentului. După vânzare, în anii următori, clădirile stabilimentului au fost dărâmate pentru construirea unor facilități moderne și, astfel, s-a așternut uitarea peste ceea ce a fost Școala Română din Franța. În anul 1997, în Parlamentul României a existat propunerea ca acest proiect interbelic să fie revitalizat, însă propunerea s-a lovit de avizul negativ al comisiilor specializate, şi niciodată nu a mai fost discutată această posibilitate.

Cuvinte-cheie: Școala Română din Franța, Nicolae Iorga, Fontenayaux-Roses, cultură română, bursă de cercetare. 